\title{
Method development to reduce the fiber content of wheat bran and rice bran through anaerobic fermentation with rumen liquor for use in poultry feed
}

\author{
Momota Rani Debi ${ }^{1}$, Brigitta A Wichert ${ }^{1}$, and Annette Liesegang ${ }^{1, *}$
}

\begin{abstract}
* Corresponding Author: Annette Liesegang Tel: +41-44-6358804, Fax: +41-44-6358939, E-mail: aliese@nutrivet.uzh.ch
\end{abstract}

1 Institute of Animal Nutrition, Vetsuisse Faculty, University of Zurich, Winterthurerstrasse 270, 8057 Zurich, Switzerland

ORCID

Momota Rani Debi

https://orcid.org/0000-0003-2443-0331 Brigitta A Wichert

https://orcid.org/0000-0002-2537-0927

Annette Liesegang

https://orcid.org/0000-0002-4292-8515

Submitted Jun 11, 2018; Revised Jul 9, 2018; Accepted Sept 10, 2018
Objective: Wheat bran (WB) and rice bran (RB) are the agricultural by-products used as poultry feed in many developing countries. However, their use for poultry feed is limited due to high fiber and the presence of anti-nutritional substances (e.g. $\beta$-glucans). The objective of this study was to develop a method to improve the quality of those brans by reducing the fiber content.

Methods: A two-step fermentation method was developed where the second fermentation of first fermented dry bran was carried out. Fermentation was performed at a controlled environment for $3 \mathrm{~h}$ and $6 \mathrm{~h}(\mathrm{n}=6)$. The composition of brans, buffer solution and rumen liquor was maintained in a ratio of 1:2:3, respectively. Brans were analyzed for dry matter, crude fiber $(\mathrm{CF})$, acid detergent fiber (ADF), neutral detergent fiber (NDF), and acid detergent lignin (ADL) content. Celluloses and hemicelluloses were calculated from the difference of ADF$\mathrm{ADL}$ and NDF-ADF, respectively. Samples were compared by two-factor analysis of variance followed by Tukey's multiple comparison tests $(\mathrm{p}<0.05)$.

Results: $\mathrm{CF} \%, \mathrm{ADF} \%$ and cellulose tended to decrease and $\mathrm{NDF} \%$ and hemicellulose content was reduced significantly $(\mathrm{p}<0.05)$. After the 1 st fermentation step, NDF decreased $10.7 \% \pm$ $0.55 \%$ after $3 \mathrm{~h}$ vs $17.0 \% \pm 0.78 \%$ after $6 \mathrm{~h}$ in case of WB. Whereas, these values were $2.3 \% \pm$ $0.30 \%(3 \mathrm{~h})$ and $7.5 \% \pm 0.69 \%(6 \mathrm{~h})$ in case of RB. However, after the 2 nd fermentation step, the decrease in the NDF content amounted to $9.1 \% \pm 0.72 \%(3 \mathrm{~h}), 17.4 \% \pm 1.13 \%(6 \mathrm{~h})$ and $9.3 \% \pm 0.46 \%(3 \mathrm{~h}), 10.0 \% \pm 0.68 \%(6 \mathrm{~h})$ in WB and RB, respectively. Cellulose and hemicellulose content was reduced up to $15.6 \% \pm 0.85 \%(\mathrm{WB}), 15.8 \% \pm 2.20 \%(\mathrm{RB})$ and $36.6 \% \pm 2.42 \%(\mathrm{WB})$, $15.9 \% \pm 3.53 \%(\mathrm{RB})$, respectively after 2 nd fermentation of $6 \mathrm{~h}$.

Conclusion: Two-step fermentation process improved the quality of the brans for their use in poultry feed.

Keywords: Fibrous Feed; Two-step Fermentation; Nutritive Value; Poultry Nutrition; Developing Countries

\section{INTRODUCTION}

In developing countries, poultry industry plays a vital role to meet the protein requirements for human nutrition. For this reason, the production efficiency of poultry to convert feed into meat is essential $[1,2]$. The problem is that quality poultry feed with reasonable prices are lacking and low production is the result in developing countries [3]. Maize and soybean meal are the major ingredients as energy and protein sources, respectively. But also human beings in developing countries consume different grains and soybean to cover their daily nutritional requirements [2]. As a consequence, to reduce the feed costs and to overcome the unavailability of quality poultry feed, some low quality agricultural by-products are used along with main ingredients [3]. Among the available sources, wheat bran (WB) and rice bran 
(RB) are the abundant and cheap agricultural by-products in rice and wheat producing countries [4] that are used as components in poultry feed [3]. Although these are inexpensive, high fiber content limits their use in poultry feed as the high fiber content reduces the digestibility of nutrients [5]. In addition, brans also contain some anti-nutritional substances e.g. $\beta$-glucans [6]. In RB and WB, the neutral detergent fiber (NDF) content varies from $33 \%$ to $40 \%$ and $48 \%$ to $51 \%$, respectively [7]. $\beta$-Glucans adversely affects the utilization of other nutrients, especially protein and starch utilization and produce highly viscous conditions in the small intestine of the chicken [8] that contribute to delayed gastrointestinal absorption. On the other hand, the digestive system of poultry is not capable to produce enzymes to hydrolyze non-starch polysaccharides [5] present in brans. Therefore, the availability of nutrients is reduced if poultry consumes these fibrous feed and that depresses the production performance [4]. Different exogenous feed enzymes have been used in poultry diet to increase the digestibility of nutrients [9]. However, the use of specific enzyme is costly in one hand and on the other hand, the effectiveness of these enzymes depends on many factors. One of the most important factor is $\mathrm{pH}$ and the catalytic activity of different enzymes depends on the $\mathrm{pH}$ level. A varied range of $\mathrm{pH}$ in the digestive tract of poultry becomes the first physiological limitation for the activity and stability of exogenous enzymes [10]. Additionally, the feed spends relatively short time in the digestive tract of poultry which is another limiting factor for ineffectiveness of exogenous feed enzymes [10]. For these reasons, it is very important to reduce the fiber content of the brans by any processing method. In this regard, fermentation with rumen liquor (containing microbes) could be an effective method to overcome these problems. Rumen microbes can synthesize $\beta$-glucanases, cellulases, and hemicellulases the enzymes required for the breakdown of cellulose, hemicelluloses and phenolic polymers $[11,12]$. Fiber is degraded by a combination of ruminal bacteria, fungi and protozoa [11], where approximately $80 \%$ of this degradation performed by bacteria and fungi and $20 \%$ by protozoa [13]. To the author's best knowledge, the use of specific fibrolytic enzymes or microbes are common methods of fermentation but limited data are available on fermentation with rumen liquor by maintaining appropriate environment for microbes to decrease the fiber content to produce high quality feed components for poultry.

First some experiments (single-step fermentation) were performed to find optimum fermentation conditions. Fermentation of WB was carried out in different composed mixtures under different environmental conditions. Fermentation was started with $48 \mathrm{~h}$ then reduced gradually $(48,36,24,12,6$, and $3 \mathrm{~h}$ ) to $3 \mathrm{~h}$ due to the instability of the $\mathrm{pH}$ for fiber degrading bacteria. It was found that, optimum $\mathrm{pH}$ (6.5) was maintained up to $3 \mathrm{~h}$ then decreased to $5.1,4.7,4.2,4.0,3.9$, and 3.8 after $6,8,12,24,36$, and 48 hours, respectively. As optimum $\mathrm{pH}$ could not be maintained, further nutrient analyses were not performed. But few samples (from $3 \mathrm{~h}$ fermentation) when analyzed it was observed that, after $3 \mathrm{~h}$ the fiber content did not decrease satisfactorily then a method with two-step fermentation was performed.

It would be feasible to implement the developed method at the industrial scale production. The new fermentation technology will be of great benefit and would probably be provided to the rice/wheat miller for the production of fermented brans in a large scale to introduce a quality product to the feed market for economic poultry ration formulation. It might also be possible to use this technology to ferment other kinds of fibrous feed for feeding other non-ruminants. A designed fermenter would be useful for industrial scale production and a fermenter might be designed to facilitate all the conditions suitable for proper growth of rumen microorganisms. In developing countries, it is promising to collect rumen liquor as well as rumen content from different slaughtered cows and goats that would be a good sources of inoculum. It might be useful to reuse the effluent after fermentation as a inoculum source for large scale production. It might also be feasible to grow rumen bacteria in a laboratory that might be useable for large scale fermented feed production.

Considering all these factors, the present study (two-step fermentation) was undertaken to systematically evaluate and compare the effect of fermentation on nutritional improvement of $\mathrm{WB}$ and $\mathrm{RB}$ after fermentation with rumen liquor. The hypothesis is that, fermentation of different kinds of brans with rumen liquor will improve their nutritive value by decreasing the fiber content. Thus the aim of this present study was to develop an easy and cheap method for optimum fermentation of high fiber feedstuffs to improve their nutritive value due to lower fiber content.

\section{MATERIALS AND METHODS}

\section{Part 1: Fermentation of wheat bran}

All experiments (fermentation and nutrient analysis) were performed at the laboratory of the Institute of Animal Nutrition, Vetsuisse faculty, University of Zurich, Switzerland according to the animal welfare law of Switzerland.

Preparation of buffer solution: McDougall buffer [14] solution $(5,000 \mathrm{~mL})$ was prepared by mixing 'Solution A' $(50 \mathrm{~mL})$ with 'Solution B' $(4,950 \mathrm{~mL})$, where the composition of this solution is given in Table 1 . The $\mathrm{pH}$ of that buffer solution was 8.1 to 8.2 and $\mathrm{pH}$ measurement was performed with a digital pH meter (827 pH lab, Metrohm AG, Herisau, Switzerland).

Collection and evaluation of rumen liquor: Rumen liquor was obtained from a cannulated Brown Swiss cow, Department for Farm Animals, Vetsuisse Faculty, University of Zurich, Switzerland that was fed with hay and concentrates for main- 
Table 1. Chemical composition of McDougall (1948) buffer solution (5,000 mL)

\begin{tabular}{lc}
\hline Constituents & Amount \\
\hline Solution-A & \\
$\mathrm{NaCl}(\mathrm{g})$ & 2.35 \\
$\mathrm{KCl}(\mathrm{g})$ & 2.85 \\
$\mathrm{CaCl} \cdot 2 \mathrm{H}_{2} \mathrm{O}(\mathrm{g})$ & 0.27 \\
$\mathrm{MgCl}_{2} \cdot 6 \mathrm{H}_{2} \mathrm{O}(\mathrm{g})$ & 0.64 \\
Distilled water $(\mathrm{mL})$ & 50 \\
Solution-B & \\
$\mathrm{NaHCO}_{3}(\mathrm{~g})$ & 49.00 \\
$\mathrm{Na}_{2} \mathrm{HPO}_{4}(\mathrm{~g})$ & 18.625 \\
Distilled water $(\mathrm{mL})$ & 4,950 \\
\hline
\end{tabular}

tenance. Rumen liquor collection was done before morning feeding [15] in a previously warmed $\left(39^{\circ} \mathrm{C}\right)[16,17]$ insulated flask that was flashed with $\mathrm{CO}_{2}$ gas before collection to maintain the anaerobic condition. After collection, the rumen liquor was filtered through a stainless steel round strainer to remove any solid particle present. After that the filtered rumen liquor was transferred immediately (within 5 minutes) into fermentation containers with constant flushing of $\mathrm{CO}_{2}$ gas to maintain anaerobic condition [17]. Simultaneously, $\mathrm{pH}$ and temperature of the rumen liquor were measured immediately following collection. The $\mathrm{pH}$ of the collected rumen liquor was within a range from 6.4 to 7.3 during the whole experiment and temperature was between $37^{\circ} \mathrm{C}$ to $40^{\circ} \mathrm{C}$. Physical characteristics such as color, odor, and consistency were recorded and a methylene blue reduction test (MBRT) was carried out to assess the amount of functional anaerobic bacteria available in the rumen liquor according to the procedure described by DePeters and George [18]. Only if the measurements indicated that collected rumen liquor was normal with an adequate amount of microbes, the fermentation was started.

Preparation offermentation mixture and fermentation (Twostep fermentation)

i) $3 \mathrm{~h}$ fermentation: Due to the results of $\mathrm{pH}$ and crude nutrient measurements after the single-step fermentation, a two-step fermentation was tested. In the two-step fermentation, a 2nd fermentation of the 1st fermented bran after drying of the mixture from the first fermentation (1st step) was performed (Figure 1). For the second fermentation step, buffer solution and rumen liquor were added again following the same procedure as in the 1st fermentation step. In that case, fermentation of WB was carried out in an Erlenmeyer flask fitted with a gas bag at $39^{\circ} \mathrm{C}$ for $3 \mathrm{~h}$. The composition of the fermentation mixture was maintained in a ratio of 1:2:3 for brans, buffer solution [14] and rumen liquor, respectively in both fermentation steps. After the 1st fermentation step, the mixtures were dried in an oven at $100^{\circ} \mathrm{C}$ and then the fermentation procedure started again (2nd step of fermentation) with this dry fermented bran. After the 2nd fermentation step, the remaining material was dried again at $100^{\circ} \mathrm{C}$. The $\mathrm{pH}$ was measured as described in the $\mathrm{pH}$ measurement schedule (Table 2). Optimum temperature $\left(39^{\circ} \mathrm{C}\right), \mathrm{pH}(6$ to 6.5$)$ as well as anaerobic condition was maintained during both steps of fermentation. Time of 1 st and 2 nd fermentation step was the same. Each fermentation step was carried out with 6 samples $(n=6)$ at 6 different days.

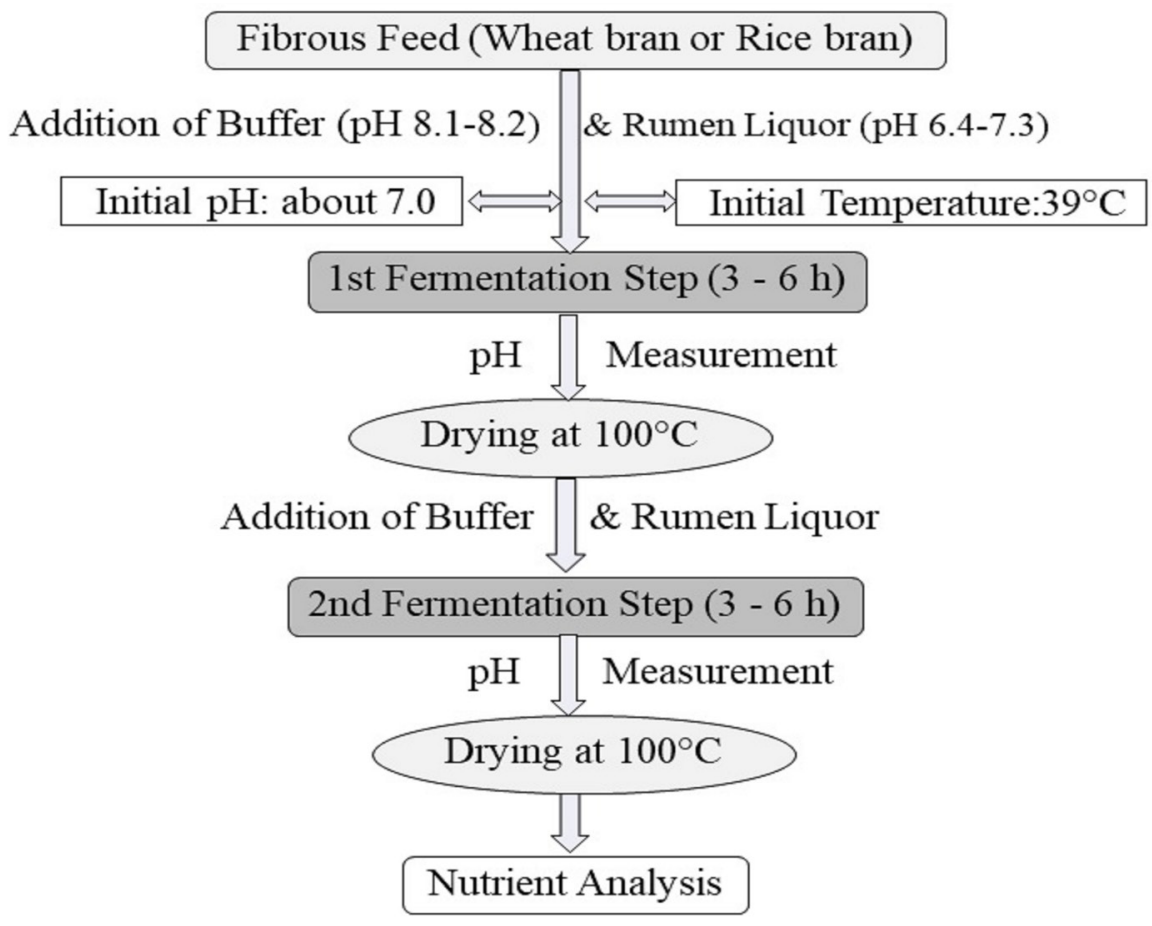

Figure 1. The design of the two step fermentation procedure of wheat bran (WB) and rice bran (RB) with rumen liquor for $3 \mathrm{~h}$ and $6 \mathrm{~h}$. 
ii) $6 \mathrm{~h}$ fermentation: Another experimental protocol that was tested was a $6 \mathrm{~h}$ fermentation with an additional buffer substance $\mathrm{NaHCO}_{3}$ ( $1 \%$ level of total mixture weight) that was added after $3 \mathrm{~h}$ to maintain an appropriate $\mathrm{pH}$ for the entire period of fermentation. This was done because after $3 \mathrm{~h}$, the $\mathrm{pH}$ started to decrease below 6 in the $3 \mathrm{~h}$ fermentation process. Due to this fact, at that point an additional buffer substance was added to increase the $\mathrm{pH}$ near to 7 . The same procedure was used in both steps of fermentation. Composition mixture of fermentation and experimental procedure was similar in the $6 \mathrm{~h}$ like in the $3 \mathrm{~h}$ fermentation. The $\mathrm{pH}$ was measured as described in the $\mathrm{pH}$ measurement schedule (Table 2).

Collection of samples: Samples were taken from different stages ( 5 stages) of this two-step fermentation process for nutrient analysis: stage 1 , fresh bran; stage 2 , bran before 1 st fermentation step, after addition of rumen liquor with buffer and bran mixture; stage 3, 1st fermented dried bran after 1st fermentation step; stage 4 , fermentation product mixture (1st fermented product+buffer+rumen liquor), before 2 nd fermentation step; and stage 5, 2nd fermented dried bran after 2nd fermentation step.

Nutrient analysis: All samples were analyzed for crude fiber (CF, proximate analysis) and van Soest fibers [19] according to the VDLUFA method book III [20]. DM was analyzed from fresh as well as dry fermented samples by drying at $105^{\circ} \mathrm{C}$ in a compartment dryer (Binder FED 53-UL Laboratory compartment dryer) for $3 \mathrm{~h}$ until weight constancy. Duplicates of each sample were analyzed and mean values were calculated. Celluloses and hemicelluloses were calculated from the difference of acid detergent fiber (ADF)-acid detergent lignin (ADL) and NDF-ADF respectively $[21,19]$ to know how much the fiber content actually decreased during the two-step fermentation process. Changes in nutrient content are given as percentage (\%).

\section{Part 2: Fermentation of rice bran}

The experimental procedure was similar as in WB fermenta-

Table 2. pH measurement schedule for $3 \mathrm{~h}$ and $6 \mathrm{~h}$ fermentation of wheat bran and rice bran

\begin{tabular}{lcc}
\hline Parameter & \multicolumn{2}{c}{ Fermentation } \\
\cline { 2 - 3 } & $3 \mathrm{~h}$ & $6 \mathrm{~h}$ \\
\hline Collected rumen liquor & $\times$ & $\times$ \\
Before 1st step & $\times$ & $\times$ \\
After 3 h of 1st step & $\times$ & $\times$ \\
After addition of NaHCO & - & $\times$ \\
After 6 h of 1st step & - & $\times$ \\
Before 2 nd step & $\times$ & $\times$ \\
After 3 h of 2 nd step & $\times$ & $\times$ \\
After addition of NaHCO & - & $\times$ \\
After 6 h of 2 nd step & - & $\times$ \\
\hline
\end{tabular}

$x, \mathrm{pH}$ was measured. tion. The only difference was in the $6 \mathrm{~h}$ fermentation. During the 2 nd step of the $6 \mathrm{~h}$ fermentation, no additional buffer substances were added as $\mathrm{pH}$ was stable enough $(\mathrm{pH}: 7)$ in that case.

\section{Statistical analysis}

Statistical analyses were performed using the statistical software package IBM SPSS, version 23 (IBM SPSS Statistics for Windows 2015, IBM Corp, New York, USA). All nutrients data were analyzed by two-way analysis of variance (ANOVA) followed by Tukey's multiple comparison tests $(\mathrm{p}<0.05)$. Factors in the analyses were time and different stages of fermentation. The $\mathrm{pH}$ measurement data were analyzed by one-way ANOVA for $3 \mathrm{~h}$ and $6 \mathrm{~h}$ separately, as $\mathrm{pH}$ measurement stages were different between $3 \mathrm{~h}$ and $6 \mathrm{~h}$ fermentation. The results are given as mean \pm standard error of mean.

\section{RESULTS}

\section{Part 1}

$p H$

i) $3 \mathrm{~h}$ fermentation: During $3 \mathrm{~h}$ fermentation, a $\mathrm{pH}$ of 6 to 6.5 was maintained in both fermentation steps and the $\mathrm{pH}$ was decreased significantly $(\mathrm{p}<0.05)$ from the initial value of 7 in both of the steps (Figure 2A).

ii) $6 \mathrm{~h}$ fermentation: The $6 \mathrm{~h}$ fermentation was started at $\mathrm{pH} 7(7.0 \pm 0.03)$ like the $3 \mathrm{~h}$ fermentation. The $\mathrm{pH}$ was significantly $(p<0.05)$ reduced after fermentation (Figure $2 \mathrm{~B})$. After the 1st fermentation step, $\mathrm{pH}$ was $5.6 \pm 0.14$. In the 2 nd fermentation step, the $\mathrm{pH}$ was not reduced as much as after the 1st step (pH 6.9 \pm 0.02$)$.

\section{Fiber content}

i) Neutral detergent fiber \%: The NDF content of WB was significantly $(\mathrm{p}<0.05)$ reduced after fermentation during the 1st (stage 2 to 3 ) and 2 nd (stage 4 to 5 ) step of fermentation for both $3 \mathrm{~h}$ ( $\mathrm{p}=0.000$ for both 1st and 2nd step) and $6 \mathrm{~h}$ (p $=0.000$ for both 1 st and 2 nd step) fermentation (Table 3 ). In that case, fermentation time had a significant effect on the NDF content and a significant $(p=0.001)$ difference was observed between $3 \mathrm{~h}$ and $6 \mathrm{~h}$ fermentation during the 2nd fermentation step. In the 1st fermentation step, NDF was reduced more during $6 \mathrm{~h}$ compared to $3 \mathrm{~h}$ fermentation but no significant difference was observed. Data on percent changes are given in Supplementary Table S1.

Crude fiber, acid detergent fiber, and acid detergent lignin \%: Analyses of the $\mathrm{CF}$ and $\mathrm{ADF}$ content data showed no significant $(\mathrm{p}<0.05)$ reduction of these nutrients after fermentation except in the 2nd step of the $6 \mathrm{~h}$ fermentation, where $\mathrm{CF}$ was significantly reduced $(\mathrm{p}=0.001)$ (Table 3$)$. Only a decreasing trend of the $\mathrm{CF}$ and $\mathrm{ADF}$ content was observed during each step for both the $3 \mathrm{~h}$ and $6 \mathrm{~h}$ fermentation without any time difference. Detailed data on percent changes are given in Sup- 
(A)

pH_3h fermentation_WB

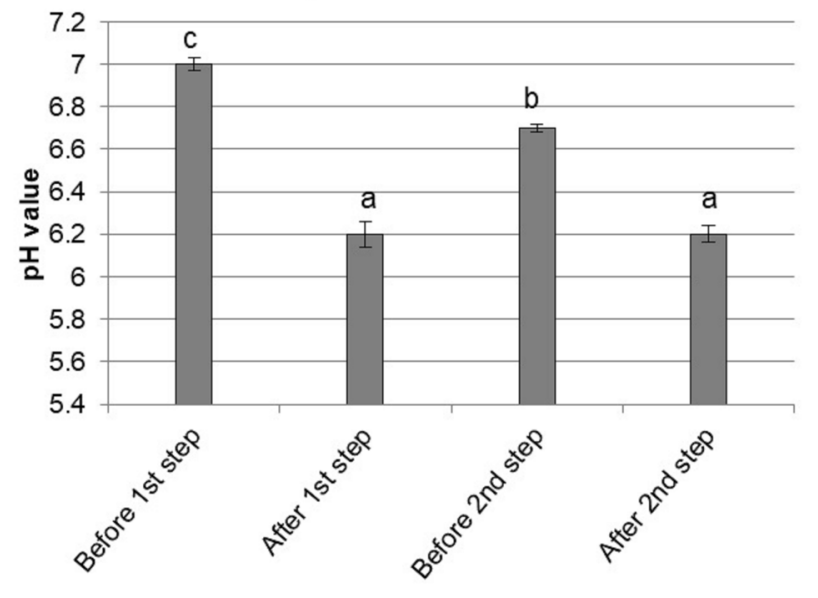

Different stages of fermentation
(B)

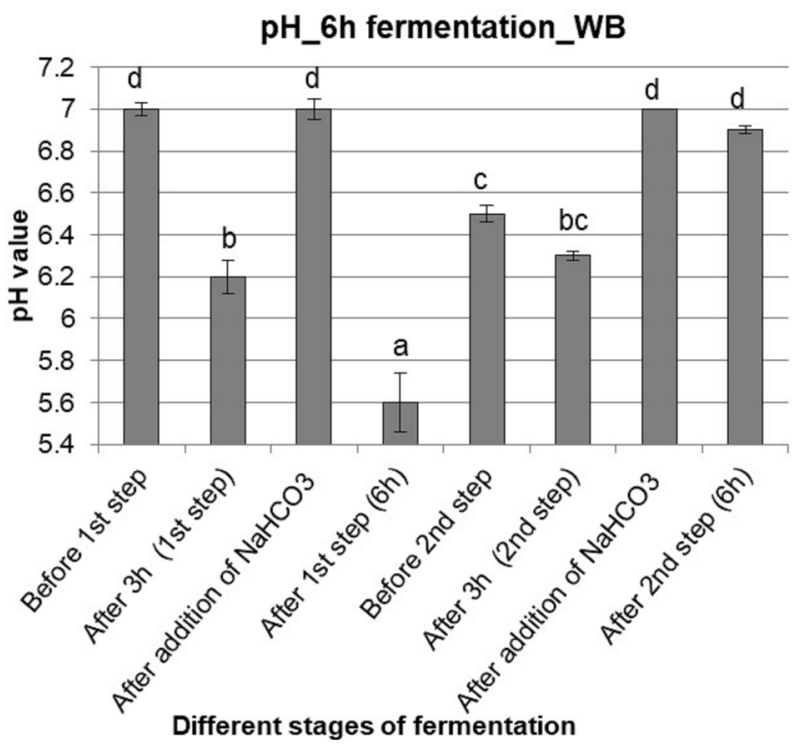

Figure 2. pH values of wheat bran (WB) fermented with rumen liquor for $3 \mathrm{~h}(\mathrm{~A})$ and $6 \mathrm{~h}$ (B). The values with different letters differ significantly at $\mathrm{p}<0.05$ level (Tukey's honestly significant difference). Values are mean \pm standard error of mean; $n=6$.

plementary Table S1. Here it could be shown that $\mathrm{CF}$ and $\mathrm{ADF}$ decreased more during $6 \mathrm{~h}$ of fermentation compared to $3 \mathrm{~h}$. Data also revealed that there were no significant $(p>0.05)$ differences of ADL content after the 1st step (stage 2 to 3 ) and 2nd step (stage 4 to 5 ) of fermentation for both $3 \mathrm{~h}$ and $6 \mathrm{~h}$ fermentation (Table 3).

Cellulose and hemicellulose \%: Data are presented in Figure $3 \mathrm{~A}$ and $3 \mathrm{~B}$ for cellulose and hemicellulose reduction, respectively. Cellulose and hemicellulose were significantly $(\mathrm{p}<0.05)$ influenced by the two-step fermentation method. Specifically, the effect of time on the reduction of hemicellulose content was significant $(\mathrm{p}<0.05)$ during both steps of fermentation. Hemicellulose was significantly more reduced $(p<0.05)$ after $6 \mathrm{~h}$ compared to $3 \mathrm{~h}$ fermentation. However, in the case of cellulose content, no significant difference was found between $3 \mathrm{~h}$ and $6 \mathrm{~h}$ fermentation.

\section{Part 2}

$p H$

i) $3 \mathrm{~h}$ fermentation: The $\mathrm{pH}$ measurement data of $3 \mathrm{~h}$ fermentation is presented in Figure 4A. During $3 \mathrm{~h}$ fermentation, an optimum $\mathrm{pH}(>6)$ was maintained in both steps of RB fer-

Table 3. Fiber fractions (\%) of wheat bran (WB) fermented with rumen liquor for $3 \mathrm{~h}$ and $6 \mathrm{~h}$

\begin{tabular}{|c|c|c|c|c|c|}
\hline \multirow{2}{*}{ Items } & \multicolumn{5}{|c|}{ Different stages of fermentation ${ }^{1)}$} \\
\hline & 1 & 2 & 3 & 4 & 5 \\
\hline \multicolumn{6}{|c|}{$3 \mathrm{~h}$ fermentation } \\
\hline NDF \% & $48.77^{\mathrm{de}} \pm 0.32$ & $49.79^{e} \pm 0.85$ & $44.47^{b c *} \pm 0.49$ & $46.49^{\text {cd }} \pm 0.82$ & $42.26^{b *} \pm 0.15$ \\
\hline CF $\%$ & $9.82^{\mathrm{abc}} \pm 0.10$ & $10.08^{b c} \pm 0.18$ & $9.55^{\mathrm{abc}} \pm 0.16$ & $9.86^{\mathrm{abc}} \pm 0.14$ & $9.39^{\mathrm{ab}} \pm 0.09$ \\
\hline ADF\% & $13.88^{\mathrm{ab}} \pm 0.21$ & $13.88^{\mathrm{ab}} \pm 0.91$ & $12.94^{\mathrm{a}} \pm 0.18$ & $14.41^{b c *} \pm 0.18$ & $13.95^{\mathrm{abc}} \pm 0.25$ \\
\hline ADL \% & $3.99^{\mathrm{a}} \pm 0.07$ & $4.43^{\mathrm{a}} \pm 0.16$ & $4.16^{a} \pm 0.07$ & $5.53^{b *} \pm 0.17$ & $5.57^{b *} \pm 0.21$ \\
\hline \multicolumn{6}{|c|}{$6 \mathrm{~h}$ fermentation } \\
\hline NDF \% & $49.60^{e} \pm 0.36$ & $50.81^{\mathrm{e}} \pm 0.71$ & $42.19^{d *} \pm 0.52$ & $46.20^{\text {cd }} \pm 0.74$ & $38.17^{\mathrm{a} *} \pm 0.71$ \\
\hline CF $\%$ & $9.87^{\mathrm{abc}} \pm 0.12$ & $10.33^{c} \pm 0.25$ & $9.60^{\mathrm{abc}} \pm 0.18$ & $10.27^{c} \pm 0.13$ & $9.13^{\mathrm{a}} \pm 0.16$ \\
\hline ADF\% & $13.48^{\mathrm{ab}} \pm 0.27$ & $14.36^{b c} \pm 0.42$ & $13.40^{\mathrm{ab}} \pm 0.27$ & $16.52^{d \star} \pm 0.37$ & $15.28^{\mathrm{cd}} \pm 0.38$ \\
\hline$A D L \%$ & $4.14^{\mathrm{a}} \pm 0.13$ & $4.81^{\mathrm{ab}} \pm 0.16$ & $5.05^{\mathrm{ab}} \pm 0.21$ & $7.44^{\mathrm{c*}} \pm 0.38$ & $7.40^{c *} \pm 0.43$ \\
\hline
\end{tabular}

$N D F$, neutral detergent fiber; $C F$, crude fiber; $A D F$, acid detergent fiber; $A D L$, acid detergent lignin.

1) Stage 1, fresh WB; Stage 2, bran before 1st fermentation step after addition of rumen liquor and buffer; Stage 3, bran after 1st fermentation step (1st fermented dried WB); Stage 4, bran before 2nd fermentation step after addition of rumen liquor and buffer with 1st fermented dried WB; Stage 5, bran after 2nd fermentation step (2nd fermented dried WB).

a-e Significant ( $p<0.05$ level; Tukey's honestly significant difference) differences between stages are given in lines by different small superscripts. Significant differences between fermentation hours at one stage are given by *

Values are mean \pm standard error of mean; $n=6$. 
(A)

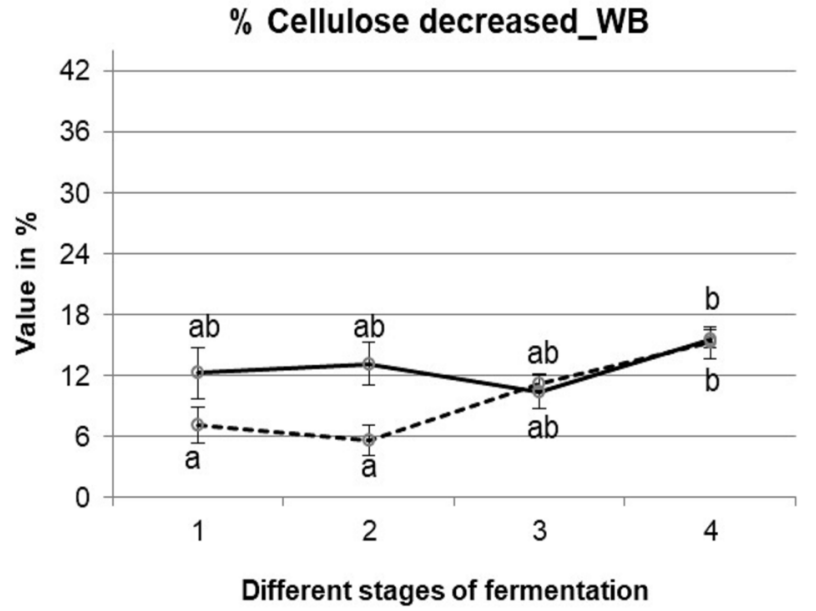

$-----3 h$ fermentation $\longrightarrow 6 \mathrm{~h}$ fermentation
(B)

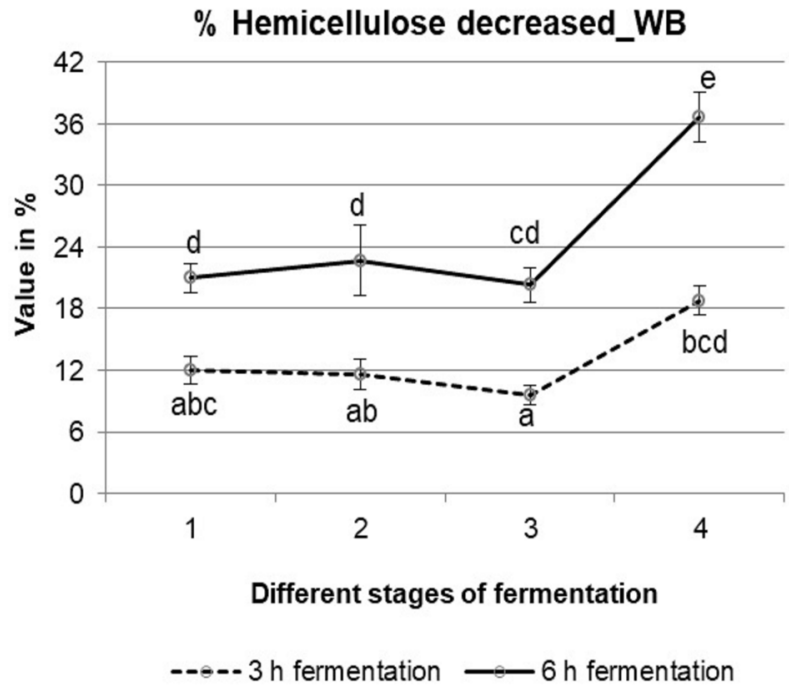

Figure 3. Content (\%) of cellulose (A) and hemicellulose (B) reduction of wheat bran (WB) fermented with rumen liquor for $3 \mathrm{~h}$ and $6 \mathrm{~h}$. Stage 1, during 1st fermentation step; Stage 2, during 2nd fermentation step; Stage 3, fresh bran to 1st fermented bran; Stage 4, fresh bran to 2nd fermented bran. The values with different letters differ significantly at $p<0.05$ level (Tukey's honestly significant difference). Values are mean \pm standard error of mean; $n=6$.

mentation. Nevertheless, the $\mathrm{pH}$ was reduced significantly $(\mathrm{p}<$ $0.05)$ during both steps of fermentation.

ii) 6 h fermentation: Data are presented in Figure 4B. In case of the 1st step of $\mathrm{RB}$ fermentation, the $\mathrm{pH}$ was similar as after WB fermentation during first $3 \mathrm{~h}$. However, the $\mathrm{pH}$ did not decrease so much while the 1st fermentation step was stopped. In the 2 nd fermentation step, the $\mathrm{pH}$ was stable without $\mathrm{NaHCO}_{3}$ up to the end of the process after $6 \mathrm{~h}$.

(A)

\section{pH_3h fermentation_RB}

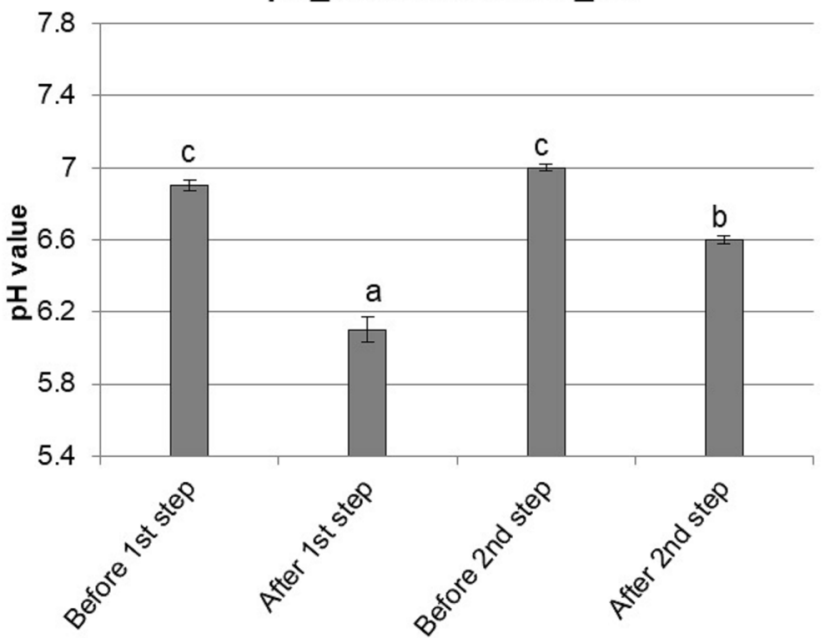

Different stages of fermentation

\section{Fiber content}

i) Neutral detergent fiber \%: The effects of fermentation on NDF content are presented in Table 4. The NDF content was reduced significantly $(\mathrm{p}<0.05)$ by two-step fermentation. During the $6 \mathrm{~h}$ fermentation, a significant reduction was found in both steps of fermentation (1st step: $\mathrm{p}=0.002$ ) and 2nd step: $\mathrm{p}=0.000)$. However, in case of $3 \mathrm{~h}$ fermentation, a significant reduction was observed during the 2 nd step of fermentation
(B)

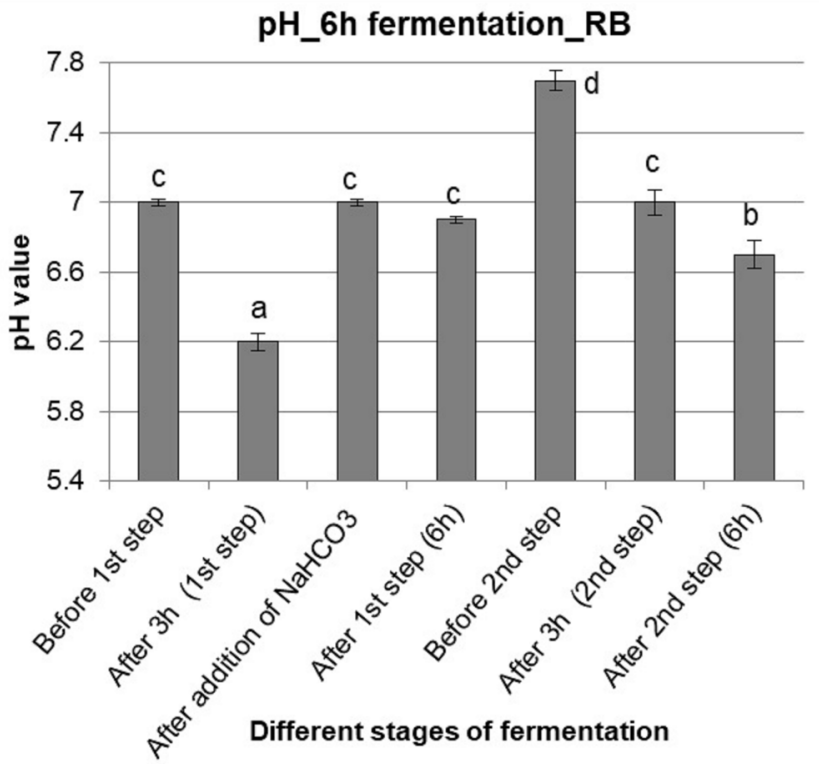

Figure 4. pH values of rice bran (RB) fermented with rumen liquor for $3 \mathrm{~h}(\mathrm{~A})$ and $6 \mathrm{~h}$ (B). The values with different letters differ significantly at $\mathrm{p}<0.05$ level (Tukey's honestly significant difference). Values are mean \pm standard error of mean; $n=6$. 
Table 4. Fiber fractions (\%) of rice bran (RB) fermented with rumen liquor for $3 \mathrm{~h}$ and $6 \mathrm{~h}$

\begin{tabular}{|c|c|c|c|c|c|}
\hline \multirow{2}{*}{ Items } & \multicolumn{5}{|c|}{ Different stages of fermentation ${ }^{1)}$} \\
\hline & 1 & 2 & 3 & 4 & 5 \\
\hline \multicolumn{6}{|c|}{$3 \mathrm{~h}$ fermentation } \\
\hline NDF \% & $40.28^{\text {cd }} \pm 0.55$ & $39.67^{b c d} \pm 0.43$ & $38.75^{\mathrm{bc}} \pm 0.54$ & $41.24^{d} \pm 0.29$ & $37.41^{\mathrm{ab}} \pm 0.56$ \\
\hline CF \% & $15.49^{\mathrm{ab}} \pm 0.26$ & $15.80^{\mathrm{abc}} \pm 0.20$ & $16.40^{b c} \pm 0.16$ & $16.53^{b *} \pm 0.28$ & $15.56^{\mathrm{abc}} \pm 0.12$ \\
\hline ADF\% & $18.91^{\complement} \pm 0.48$ & $18.70^{b c} \pm 0.34$ & $18.30^{\mathrm{abc}} \pm 0.12$ & $18.80^{c} \pm 0.19$ & $17.23^{\mathrm{a}} \pm 0.26$ \\
\hline ADL \% & $6.92^{\mathrm{a}} \pm 0.04$ & $7.36^{\mathrm{ab}} \pm 0.13$ & $7.39^{\mathrm{ab}} \pm 0.12$ & $7.80^{\mathrm{bc}} \pm 0.11$ & $7.06^{\mathrm{ab}} \pm 0.20$ \\
\hline \multicolumn{6}{|c|}{$6 \mathrm{~h}$ fermentation } \\
\hline NDF \% & $39.98^{\text {cd }} \pm 0.26$ & $41.23^{d} \pm 0.33$ & $38.16^{b c} \pm 0.65$ & $39.19^{b c d} \pm 0.46$ & $35.27^{\mathrm{a}} \pm 0.62$ \\
\hline CF \% & $15.70^{\mathrm{abc}} \pm 0.12$ & $15.80^{\mathrm{abc}} \pm 0.13$ & $15.49^{\mathrm{ab}} \pm 0.22$ & $16.57^{c *} \pm 0.38$ & $15.05^{\mathrm{a}} \pm 0.15$ \\
\hline ADF\% & $18.73^{c} \pm 0.16$ & $18.32^{\mathrm{abc}} \pm 0.28$ & $17.09^{\mathrm{a}} \pm 0.18$ & $19.08^{\complement} \pm 0.33$ & $17.43^{\mathrm{ab}} \pm 0.15$ \\
\hline ADL \% & $6.93^{\mathrm{a}} \pm 0.06$ & $7.26^{\mathrm{ab}} \pm 0.14$ & $7.11^{a} \pm 0.11$ & $8.34^{c} \pm 0.23$ & $7.51^{b c} \pm 0.07$ \\
\hline
\end{tabular}

NDF, neutral detergent fiber; $C F$, crude fiber; $A D F$, acid detergent fiber; $A D L$, acid detergent lignin.

1) Stage 1, fresh RB; Stage 2, bran before 1st fermentation step after addition of rumen liquor and buffer; Stage 3, bran after 1st fermentation step (1st fermented dried RB); Stage 4, bran before 2nd fermentation step after addition of rumen liquor and buffer with 1st fermented dried RB; Stage 5, bran after 2nd fermentation step (2nd fermented dried RB).

${ }^{a-d}$ Significant ( $p<0.05$ level; Tukey's honestly significant difference) differences between stages are given in lines by different small superscripts. Significant differences between fermentation hours at one stage are given by *.

Values are mean \pm standard error of mean; $n=6$.

only. Detailed data on percent changes are given in Supplementary Table S1.

ii) Crude fiber, acid detergent fiber, and acid detergent lignin \%: Data of CF, ADF, and ADL content are presented in Table 4. CF content was reduced significantly $(p=0.000)$ only in the 2 nd step of the $6 \mathrm{~h}$ fermentation. In case of ADF content, there was a significant reduction observed in the 2 nd step of both $3 \mathrm{~h}(\mathrm{p}=0.006)$ and $6 \mathrm{~h}(\mathrm{p}=0.003)$ fermentation. There was no significant difference observed in case of $\mathrm{ADL}$ content during both $3 \mathrm{~h}, 6 \mathrm{~h}$, and 1st and 2nd step of fermentation.

iii) Cellulose and hemicellulose \%: Percentages of cellulose

(A)

$\%$ Cellulose decreased_RB

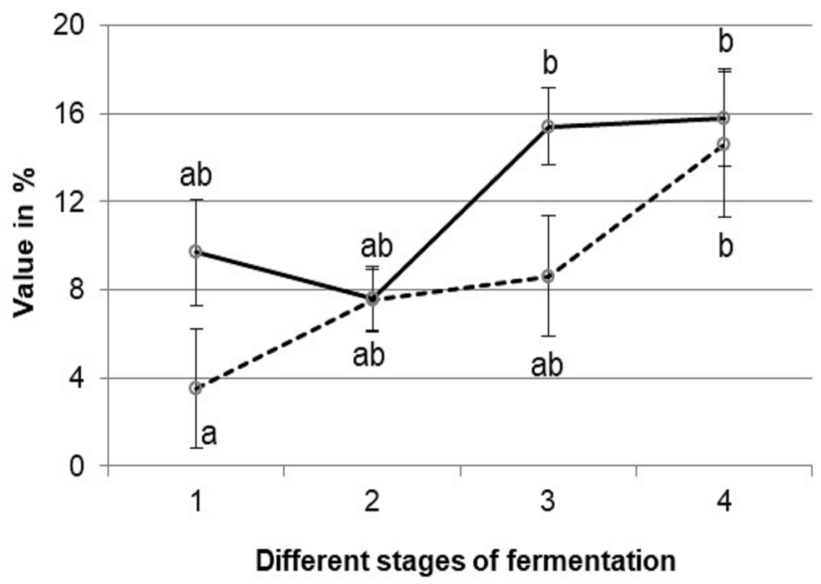

$--\bullet--3 \mathrm{~h}$ fermentation $\longrightarrow 6 \mathrm{~h}$ fermentation and hemicellulose reduction of fresh bran as well as fermented $\mathrm{RB}$ are presented in Figure 5A and 5B, respectively. No significant difference was observed in cellulose reduction during RB fermentation. Hemicellulose was reduced more after $6 \mathrm{~h}$ compared to $3 \mathrm{~h}$ fermentation and a significant $(\mathrm{p}=0.015)$ lower hemicellulose content was measured in the 2 nd fermented bran compared to the 1st fermented bran after $6 \mathrm{~h}$ fermentation.

\section{DISCUSSION}

(B)

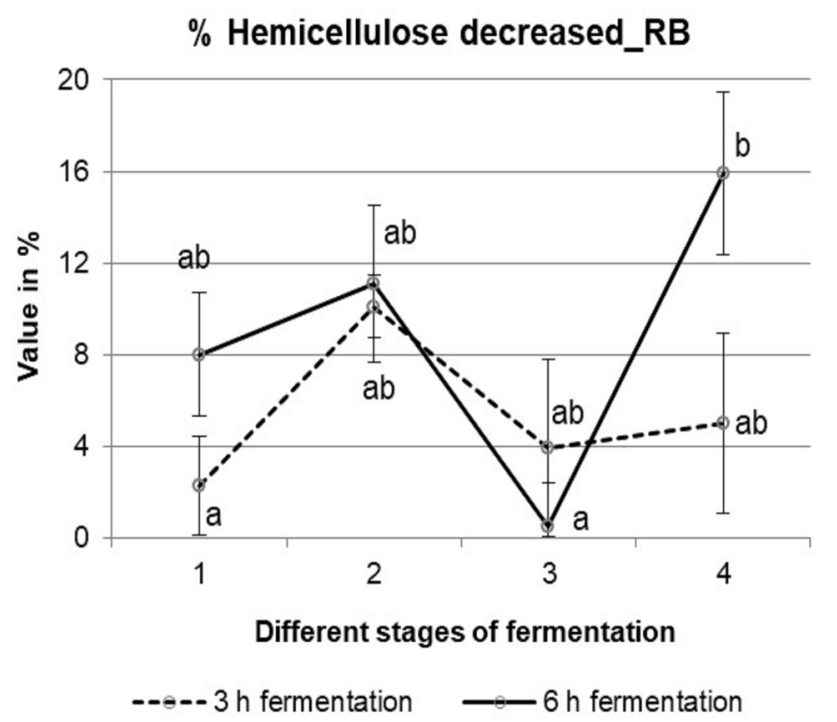

Figure 5. Content (\%) of cellulose (A) and hemicellulose (B) reduction of rice bran (RB) fermented with rumen liquor for $3 \mathrm{~h}$ and $6 \mathrm{~h}$. Stage 1, during 1 st fermentation step; Stage 2, during 2nd fermentation step; Stage 3, fresh bran to 1st fermented bran; Stage 4, fresh bran to 2nd fermented bran. The values with different letters differ significantly at $p<0.05$ level (Tukey's honestly significant difference). Values are mean \pm standard error of mean; $n=6$. 
In the present investigation, a two-step fermentation was performed after examining the results of some initial experiments (single-step fermentation) of this study that were conducted based on some in-vitro studies [22,23] such as rumen simulation technique (RUSITEC). However, RUSITEC systems are not useful for commercial feeding purpose or industrial use. A major problem to continue the single-step (initial experiments) fermentation for a longer period of time is the decrease of $\mathrm{pH}$ of the fermented mixture with increasing the time of fermentation. Due to these facts, the single-step fermentation was not continued. However, it seemed to be necessary to increase the fermentation time to increase the chances of microbe growth and with this the production of fiber degrading enzymes [11]. To overcome these problems, a two-step fermentation method was developed. It was assumed that most of the components that require less time to degrade, would be fermented during the 1st step of fermentation and that the amount of fiber would be reduced in the 2 nd fermentation step. The 1st fermentation step was stopped when the $\mathrm{pH}$ decreased to a level of $<6$ that is known to be incompatible with the growth of fiber degrading bacteria.

The $\mathrm{pH}$ is one of the most important factors for ruminal microorganisms for the fermentation of fibrous components $[24,25]$. The appropriate range of rumen $\mathrm{pH}$ should be between 6 and 7 if cow maintain with proper ratio of grass and concentrate with good physiological conditions and a $\mathrm{pH}$ lower than that decreases the extent of fiber degradation process $[26,27]$. In the present study, the $\mathrm{pH}$ was reduced significantly after each step of fermentation and continued to decrease with increasing fermentation time. Also rumen $\mathrm{pH}$ (in live animal) changes constantly and depends on several factors e.g. the production of saliva, the generation and absorption of volatile fatty acids (VFA), the type and level of feed intake, and the exchange of buffer through the ruminal epithelium [28]. In the used in-vitro system most likely the $\mathrm{pH}$ was reduced due to the formation of VFA [27-29] and lactic acids [27,28] during fermentation and accumulation of these acids [30]. As a weak acid, these organic acids rapidly dissociate and release a proton and thereby decrease $\mathrm{pH}$ under most circumstances. As our fermentation system was completely closed, absorption or removal of VFA or other acidic components were not possible. For this reason, additional buffer substances $\mathrm{NaHCO}_{3}$ were added to increase the $\mathrm{pH}$ and with this the fermentation capability of the system. As an appropriate $\mathrm{pH}$ (6 to 6.5) could maintained only during the $3 \mathrm{~h}$ fermentation, the additional buffer substance was added to control $\mathrm{pH}$ during the $6 \mathrm{~h}$ fermentation. $\mathrm{NaHCO}_{3}$ is a potent buffer to prevent acidic conditions in the rumen or used in in-vitro system [31,24] and with this produce appropriate fermentation conditions. Although the procedure used for fermentation was the same in $\mathrm{RB}$ as in $\mathrm{WB}$, different $\mathrm{pH}$ values from $\mathrm{WB}$ to $\mathrm{RB}$ were measured during the whole fermentation process. This might be due to the compositional variation of $\mathrm{WB}$ and $\mathrm{RB}$. At the end of the 2nd step of $6 \mathrm{~h}$ fermentation, $\mathrm{pH}$ was not as much reduced as after the 1st step and remained near to 7 . This may indicate that most of the components of brans that degraded quickly were fermented during the 1st fermentation step. In future, the question should be answered if a longer 2nd fermentation would be useful to improve the nutritional value of the brans.

In the described fermentation system, fiber was degraded more during $6 \mathrm{~h}$ compared to $3 \mathrm{~h}$ fermentation and the fiber was decreased more in the 2 nd fermentation step. This could be expected as fermentation time is a very important factor for fiber degradation and Wizna et al [32] reported that the fermentation time had a greater influence than the inoculum dose. Longer fermentation time at ideal temperature and $\mathrm{pH}$ condition means a higher amount of microbes within the fermentation process. A too short fermentation time might be the reason for the slow degradation of fiber during the 1st step of fermentation and also in the $3 \mathrm{~h}$ fermentation compared to 2nd step and $6 \mathrm{~h}$ fermentation. Jazi et al [33] reported that fermentation of cotton seed meal with Bacillus subtilis, Aspergillus niger and A. oryzae for 7 days significantly $(\mathrm{p}<0.05)$ reduced $\mathrm{CF}(34.73 \%$, from $12.58 \%$ to $8.21 \%$ ). Also during fermentation of RB with Bacillus amyloliquefaciens and humic substances for 3 and 5 days, CF was reduced from $10.62 \%$ to $8.37 \%$ and $8.36 \%$, respectively [4]. Conversely, Aanuoluwapo and Gbenga [34] found that CF increased from $6.25 \%$ to $6.89 \%$ when WB was fermented with rumen liquor where the mixture of WB and rumen liquor were put in a polythene bags and kept under the soil for 3 days. They did not mention anything about the $\mathrm{pH}$ and temperature of the fermented mixture that are very important determinants for cellulose degrading bacteria. In the present investigation, the appropriate environments $(\mathrm{pH}$, temperature, anaerobic condition) were maintained during the whole fermentation period. In this study, NDF content was clearly reduced in the 2nd fermented WB after $6 \mathrm{~h} \mathrm{com-}$ pared to fresh bran. The fiber reduction was higher in WB compared to RB. Probably, the reasons for these differences are the different compositions of $\mathrm{WB}$ and $\mathrm{RB}$. RB contains less crude protein (CP) than WB. Previous studies reported that cellulolytic bacteria increased significantly $(\mathrm{p}<0.05)$ with increasing level of CP content in the diet whereby increased fiber degradability $[35,36]$. Also in beef cattle and dairy cattle in other studies [37,38], the NDF degradability tended to increase with increasing dietary $\mathrm{CP}$ levels. Another reason could be the higher crude fat content in RB compared to WB which ranges from $4.07 \%$ to $19.31 \%$ depending on the sources of collection [6]. This might be another reason for slower degradation of fiber in RB compared to WB. A high fat content coats the dietary fiber and therefore interferes with the fiber degradation $[39,40]$. Additionally, RB has more lignification than WB. Due to the presence of strong covalent bonds between lignin 
and the cell wall polysaccharides, it reduces the accessibility for the enzymatic hydrolysis secreted by rumen microbes [41] and thereby reduces fiber degradation. In the present study, the lignin content was not changed significantly by fermentation because of rumen microbes can not synthesize lignin degrading enzymes. This is in agreement with van Soest [41]. However, it was observed that the ADL content of fermented bran was higher compared to fresh bran after both 1st and 2nd fermentation step. The reason for this could be a relative increase of lignin as other fiber components were degraded during fermentation and with this the ADL content that not degraded by fermentation, increased relatively [41].

The results obtained in this study suggest that fermentation of $\mathrm{WB}$ and $\mathrm{RB}$ with rumen liquor improved their nutritional value by decreasing the fiber content. Fiber degradation was strongly influenced by the time of fermentation and a 2nd fermentation step had a significant effect on fiber reduction compared to the 1st fermentation step. Further the procedure of fermentation should be adjusted according to the fermented feed-stuffs. In all in-vitro fermentation of feed stuffs to improve their nutritive value seems to be an easy but effective method. However, in future, the method should be optimized by a longer fermentation time and the improvement of nutritive value, especially the changes of amino acid (AA) profile should be investigated. Additionally, the method should be adapted for an industrial use for the improvement of the nutritional quality of different kinds of fibrous feed to be able to produce meat at affordable price. This would help to provide humans in the third world with AAs in a sufficient amount.

\section{CONFLICT OF INTEREST}

We certify that there is no conflict of interest with any financial organization regarding the material discussed in the manuscript.

\section{ACKNOWLEDGMENTS}

The Authors thank Prof. Dr. Rupert M. Bruckmaier, University of Bern, Prof. Dr. Thomas A. Lutz, University of Zurich, and Prof. Dr. Khan Md. Shaiful Islam, Bangladesh Agricultural University for their suggestions. Authors also thank the Federal Commission for Scholarships for Foreign Students (FCS) for the financial support as well as Ines Mittner and Reto Muhlemann for their technical assistance.

\section{REFERENCES}

1. Sell-Kubiak E, Wimmers K, Reyer H, Szwaczkowski T. Genetic aspects of feed efficiency and reduction of environmental footprint in broilers: a review. J Appl Genet 2017;58:487-98.

2. Mottet A, Tempio G. Global poultry production: current state and future outlook and challenges. World's Poult Sci J 2017; 73:245-56.

3. Ravindran V. Poultry development review: Poultry feed availability and nutrition in developing countries. Rome, Italy; Food and Agriculture Organization of the United Nations. 2013.

4. Supriyati T, Haryati T, Susanti, Susana IWR. Nutritional value of rice bran fermented by Bacillua amyloliquefaciens and humic substances and its utilization as a feed ingredient for broiler chicken. Asian-Australas J Anim Sci 2015;28:231-8.

5. Kras RV, Kessler AM, Ribeiro AML, et al. Effect of dietary fiber and genetic strain on the performance and energy balance of broiler chickens. Braz J Poult Sci 2013;15:15-9.

6. Satinder K, Savita S, Nagi HPS. Functional properties and anti-nutritional factors in cereal bran. Asian J Food Agro-Ind 2011;4:122-31.

7. Tahir MI, Khalique A, Pasha TN, Bhatti JA. Comparative evaluation of maize bran, wheat bran and rice bran on milk production of Holstein Friesian cattle. Int J Agric Biol 2002;4: 559-60.

8. Hasselman K, Aman P. The effect of $\beta$-glucanase on the utilization of starch and nitrogen by broiler chicks fed on barley of low- or high viscosity. Anim Feed Sci Technol 1986;15:8393.

9. Munir K, Maqsood S. A review on role of exogenous enzyme supplementation in poultry production. Emir J Food Agric 2013;25:66-80.

10. Ravindran V. Feed enzymes: The science, practice, and metabolic realities. J Appl Poult Res 2013;22:628-36.

11. Wang Y, McAllister TA. Rumen microbes, enzymes and feed digestion-a review. Asian-Australas J Anim Sci 2002;15:165976.

12. Adeyemi OA, Familade FO. Replacement of maize by rumen filtrate fermented corn-cob in layer diets. Bioresour Technol 2003;90:221-4.

13. Dijkstra J, Tamminga S. Simulation of the effects of diet on the contribution of rumen protozoa to degradation of fiber in the rumen. Br J Nutr 1995;74:617-34.

14. McDougall EI. Studies on ruminant saliva. 1. The composition and output of sheep's saliva. Biochem J 1948;43:99-109.

15. Shen J, Liu Z, Yu Z, Zhu W. Monensin and Nisin affect rumen fermentation and microbiota differently in vitro. Front Microbiol 2017;8:1111.

16. Sechler SR, Mullenix MK, Holland CM, Muntifering RB. Fiber digestion kinetics and protein degradability characteristics of stockpiled Tifton 85 bermudagrass. J Anim Sci 2017;95:392231.

17. Weiss CP, Gentry WW, Cole NA, McCollum III FT, Jennings JS. Effects of feeding condensed distiller's solubles and crude glycerin alone or in combination on finishing beef cattle performance, carcass characteristics, and in vitro fermentation. J Anim Sci 2017;95:922-9.

18. DePeters EJ, George LW. Collection of rumen fluid [Internet]. 
Progressive Dairyman: US; c2015 [cited 2015 Jan 21]. Available from:https://www.progressivedairy.com/topics/herd-health/ collection-of-rumen-fluid

19. Van Soest PJ, Robertson JB, Lewis BA. Methods for dietary fiber, neutral detergent fiber, and nonstarch polysaccharides in relation to animal nutrition. J Dairy Sci 1991;74:3583-97.

20.Naumann C, Bassler R. The chemical analysis of feed stuff. In: Method Book, Volume III, 3rd VDLUFA Verlag, Darmstadt, Germany, 1997.

21.Lopez D, Vazquez AJF, Lopez VN, et al. In vitro gas production of foliage from three browse tree species treated with different dose levels of exogenous fibrolytic enzymes. J Anim Physiol Anim Nutr 2016;100:920-8.

22. Duarte AC, Durmic Z, Vercoe PE, Chaves AV. Dose-response effects of dietary pequi oil on fermentation characteristics and microbial population using a rumen simulation technique (Rusitec). Anaerobe 2017;48:59-65.

23. Duarte AC, Holman DB, Alexander TW, et al. The type of forage substrate preparation included as substrate in a RUSITEC system affects the ruminal microbiota and fermentation characteristics. Front Microbiol 2017;8:704.

24. Santra A, Chaturvedi OH, Tripathi MK, Kumar R, Karim SA. Effect of dietary sodium bicarbonate supplementation on fermentation characteristics and ciliate protozoal population in rumen of lambs. Small Rumin Res 2003;47:203-12.

25. Grant RJ, Weidner SJ. Digestion kinetics of fiber: influence of in vitro buffer $\mathrm{pH}$ varied within observed physiological range. J Dairy Sci 1992;75:1060-8.

26. Mourino F, Akkarawongsa R, Weimer PJ. Initial $\mathrm{pH}$ as a determinant of cellulose digestion rate by mixed ruminal microorganisms in vitro. J Dairy Sci 2001;84:848-59.

27. Dijkstra J, Ellis JL, Kebreab E, et al. Ruminal pH regulation and nutritional consequences of low $\mathrm{pH}$. Anim Feed Sci Technol 2012;172:22-33.

28. Aschenbach J, Penner GB, Stumpff F, Gäbel G. Ruminant nutrition symposum: Role of fermentation acid absorption in the regulation of ruminal pH. J Anim Sci 2011;89:1092-107.

29. Sato S. Pathophysiological evaluation of subacute ruminal acidosis (SARA) by continuous ruminal pH monitoring. Anim Sci J 2016;87:168-77.

30. Chibisa GE, Beauchemin KA, Penner GB. Relative contribution of ruminal buffering systems to $\mathrm{pH}$ regulation in feedlot cattle fed either low or high-forage diets. Animal 2016;10:1164-72.

31.Cruywagen CW, Taylor S, Beya MM, Calitz T. The effect of buffering dairy cow diets with limestone, calcareous marine algae, or sodium bicarbonate on ruminal $\mathrm{pH}$ profiles, production responses, and rumen fermentation. J Dairy Sci 2015;98: 5506-5514.

32. Wizna, Abbas H, Rizal Y, et al. Improving the Quality of Sago pith and rumen content mixture as poultry feed through fermentation by Bacillus amyloliquefaciens. Pak J Nutr 2008;7: 249-54.

33. Jazi V, Boldaji F, Dastar B, Hashemi SR, Ashayerizadeh A. Effects of fermented cottonseed meal on the growth performance, gastrointestinal microflora population and small intestinal morphology in broiler chickens. J Br Poult Sci 2017;58:402-8.

34. Aanuoluwapo AA, Gbenga EO. Growth performance, haematology and meat quality of broiler chickens fed rumen liquorfermented wheat bran-based diets. Jordan J Agric Sci 2014;10: 725-36.

35.Liu Q, Wang C, Li HQ, et al. Effects of dietary protein levels and rumen-protected pantothenate on ruminal fermentation, microbial enzyme activity and bacteria population in Blonde d'Aquitaine $\times$ Simmental beef steers. Anim Feed Sci Technol 2017;232:31-9.

36. Reis WLS, Detmann E, Batista ED, et al. Effects of ruminal and post-ruminal protein supplementation in cattle fed tropical forages on insoluble fiber degradation, activity of fibrolytic enzymes, and the ruminal microbial community profile. Anim Feed Sci Technol 2016;218:1-16.

37. Da Silva LD, Pereira OG, Silva TCD, Valadares FSC, Ribeiro KG. Effects of silage crop and dietary crude protein levels on digestibility ruminal fermentation, nitrogen use efficiency, and performance of finishing beef cattle. Anim Feed Sci Technol 2016;220:22-33.

38. Ouellet DR, Chiquette J. Effect of dietary metabolizable protein level and live yeasts on ruminal fermentation and nitrogen utilization in lactating dairy cows on a high red clover silage diet. Anim Feed Sci Technol 2016;220:73-82.

39. Pantoja J, Firkins JL, Eastridge ML, Hull BL. Effects of fat saturation and source of fiber on site of nutrient digestion and milk production by lactating dairy cows. J Dairy Sci 1994;77:234156.

40. Oldick BS, Firkins JL. Effects of degree of fat saturation on fiber digestion and microbial protein synthesis when diets are fed twelve times daily. J Anim Sci 2000;78: 2412-20.

41. Van Soest PJ. Nutritional ecology of the ruminant. 2nd. ed. Ithaca, NY, USA: Cornell University Press; 1994. 476 p. 